
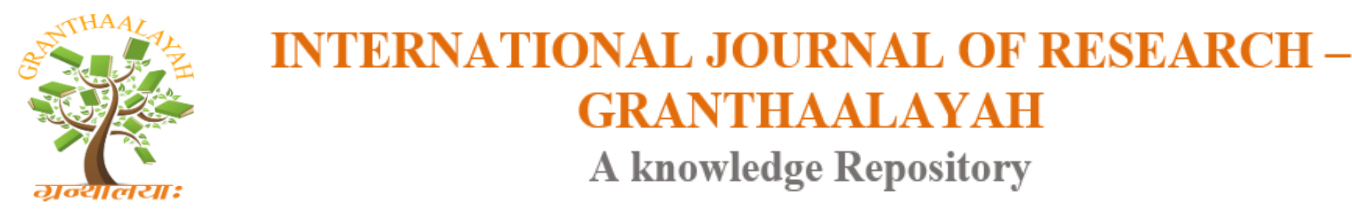

Science

\title{
ANALYSIS OF FOOD CONSUMPTION PREFERENCES AND FOOD DEMAND IN CENTRAL JAVA, INDONESIA
}

\author{
Faiqoh Amalina ${ }^{* 1}$, Ratya Anindita ${ }^{2}$, Dan Abdul Wahib Muhaimin ${ }^{2}$ \\ ${ }^{1}$ Master's Degree, Agricultural, University of Brawijaya, Malang, Indonesia \\ ${ }^{2}$ Lecturer, Agricultural, University of Brawijaya, Malang, Indonesia
}

\begin{abstract}
The efforts of the Government in food diversification of rice to local food thus generating household conditions that tend to switch to wheat consumption compared to local commodities. So the necessary analyse to look at preferences in consuming the food commodities. Besides seeing the influence of price changes and the expenditure against the demand for food as the evaluation of food diversification successfully implemented. This analysis were using Susenas data (2016) analyzed by the Linear Approximation/Almost Ideal Demand System (LA/AIDS) model. The results of the analysis note that the highest preference is present on rice and flour, seen from the amount of consumption as well as the proportion of its expenditure. The results of the demand elasticity indicates that diversifies effort still hadn't done very well because there were still a dependency of the rice. So that the effort to maintain the affordability of the rice should still be enacted.
\end{abstract}

Keywords: Diversification; Food; LA/AIDS; Preference; Elasticity; Budget Share.

Cite This Article: Faiqoh Amalina, Ratya Anindita, and Dan Abdul Wahib Muhaimin. (2017). "ANALYSIS OF FOOD CONSUMPTION PREFERENCES AND FOOD DEMAND IN CENTRAL JAVA, INDONESIA." International Journal of Research - Granthaalayah, 5(12), 256-265. https://doi.org/10.29121/granthaalayah.v5.112.2017.501.

\section{Introduction}

The proportion of expenditure per household for food is greater from non-food of $53.17 \%$. This becomes a concern when food availability was not able to meet the demand of consumers. The increase in population, food prices, as well as the environmental conditions which affect the production has been noted by the Government in maintaining the availability of food (Ariani, 2010). One of the efforts that are being undertaken vigorous Government is an attempt to diversify food commodities especially to the carbohydrates source so as not to depend on the rice commodity, but can also be diversifying the other local commodities (Badan Ketahanan Pangan, 2014). 
At the year of 2011, the values of consumption of rice still reach i.e. $102.8 \mathrm{~kg} / \mathrm{capita} /$ year. Food diversification effort was only able to bring down the rate of growth of consumption of rice amounted to $1.16 \%$ in 2015 . But the decline also local food consumption of cassava $9.14 \%$. While the increase in the rate of consumption in the other local commodity only amounted to $1.26 \%$ to corn and $5.77 \%$ to sweet potatoes. However, the more things to note is the increase in consumption for a fairly high of import commodities of wheat flour consumption which increased by $13.13 \%$ (Kementerian Pertanian, 2015).

Changes in the rate of consumption of each commodity explain the change of food consumer preferences against food consumption happened. The Changes in consumer behaviour in consumption based on commodity price and income changes (Nicholson, 1995; Koutsoyiannis, 1982). If It was viewed from a shift in food consumption going on shift to wheat consumption commodities seen from the proportion of consumption that are experiencing rapid increases. It is clear that the efforts of food diversification to rice does look successful, but the transfer did not lead to local food and switched to wheat flour instead, the value of imports of wheat every year continues to increase and now Indonesia as the fourth-largest wheat importer country of the world (United States Department of Agriculture, 2017). Therefore, the necessary of demand preference analysis to the carbohydrate sources as the image of the trend in household spending budgets allocate a longer in consuming food. As well as the analysis of the elasticity of demand as one way to evaluate the success of an effort to diversify the local food.

\section{Methods}

\subsection{Research Location}

The location is determined purposively in the province of Central Java, because It has the most rural areas compared to other provinces (Central Bureau of statistics, 2017). This is because a rural area is the region with the high percentage of expenditure for food commodities rather than in urban areas (Badan Pusat Statistik, 2017).

\subsection{Research Data}

The data was from National social economic survey (Susenas) the year of 2016 consumption and expenditure module in Central Java province from Badan Pusat Statistik (BPS). From the Susenas, researchers using related data total spending on consumption, expenditure and consumption quantities for each commodity (rice, maize, cassava, sweet potato, and wheat flour), as well as data of family members and household demographics.

\subsection{Data Analysis}

The preferences analysis of household consumption was done with the approach of the expenditure proportion of every household, the equation as follow:

$$
w_{i}=\frac{b_{i}}{x} \times 100 \%=\frac{p_{i} \cdot q_{i}}{\sum p_{i} \cdot q_{i}} \times 100 \%
$$


Where $\mathrm{w} \_\mathrm{i}$ is the proportion of commodity expenditure $\mathrm{i}$; bi that is commodity expenditures $\mathrm{i}$; $\mathrm{x}$ which is the total expenditure of the primary food; pi is the commodity price $i$; qi is the purchase quantity.

Analysis of the food demand estimation is done with a Linear Approximation/ Almost Ideal Demand System (LA/AIDS) model. LA/AIDS model is a linear model of demand derived from the Marshallian in proportion to the expenditures or budget share (Deaton and Muellbauer, 1980). LA/AIDS Model was being estimated using Seemingly Unrelated Regression (SUR). SUR is a system of multivariate regression estimation in which explains that the values of any model equations are not mutually correlated (unrelated). So each model equation analysis can be performed simultaneously without causing the correlation between his model (Zellner, 1962). The equations of the LA/AIDS model are as follows:

$$
w_{i}=\frac{b_{i}}{x} \times 100 \%=\frac{p_{i} \cdot q_{i}}{\sum p_{i} \cdot q_{i}} \times 100 \%
$$

Where $w \_i$ is the proportion of food expenditure to- $i, p_{-} j$ is commodity prices to-j, $x$ is the total spending for food, $\alpha, d, \beta, \gamma$, is the estimation parameter, and $\mu$ is the error term. Whereas $i, j$ is the code to 1 (rice), 2 (maize), 3 (cassava), 4 (sweet potato), 5 (wheat flour). $\mathrm{p}^{*}$ is the price index

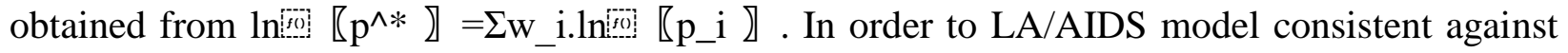
the theory of demand, then the use of the AIDS model in demand system should followed the retriksi request that consists of adding up, homogeneity, and symmetry.

Adding up $\quad: \sum_{i} a_{i}=1, \sum_{i} a_{i j}=0, \sum_{i} b_{i}=0$,

Homogeneity $: \sum_{j} c_{i j}=0$,

Symmetry $: c_{i j}=c_{j i}$.

In this analysis test of the adding-up was not done because of the restriction of can be fulfilled directly when the variable of the expenditure share, price index as well as expenditure calculated in the model (Liao and Chern, 2007; Hasab and Abdelrahman 1990).

The results of the model estimation of LA/AIDS can be used for the calculation of demand elasticity. This analysis used two approach methods to calculate the demand elasticity, i.e. the Marshallian and Hicksian approach. Both of the approaches were used because there is a difference of the effect given, the existence of income effect and substitution effect on Marshallian analysis. Whereas, Hicksian only give the substitution effect (Nicholson, 1995; Crosetto, 2010). The elasticities are computed as follows:

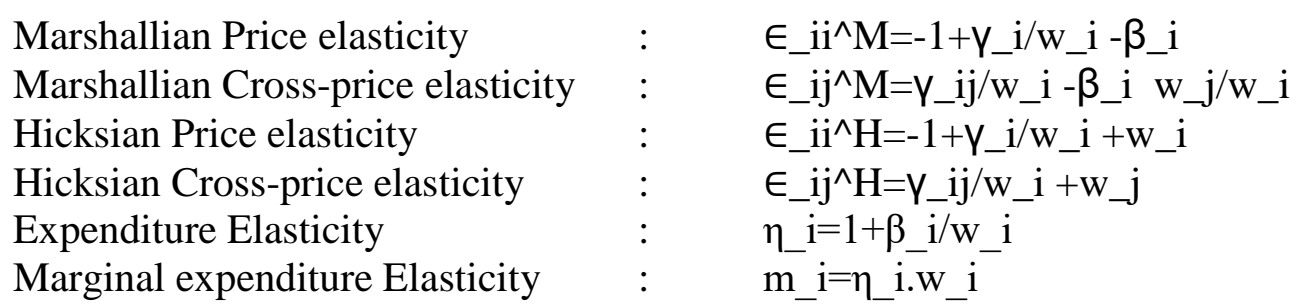


Where $\epsilon_{-} \mathrm{ii}^{\wedge} \mathrm{M}$ is the Marshallian price elasticity, $\epsilon_{-} \mathrm{ij}^{\wedge} \mathrm{M}$ is the Marshallian cross elasticity, the $\epsilon_{-} \mathrm{ii}{ }^{\wedge} \mathrm{H}$ is the Hicksian price elasticity, $\epsilon_{-} \mathrm{ij}{ }^{\wedge} \mathrm{H}$ is the Hicksian cross price elasticity, $\eta \_i$ is the expenditure elasticity, $\mathrm{m} \_\mathrm{i}$ is Marginal expenditure elasticity, $\mathrm{w}_{-} \mathrm{i}$ is the proportion of expenditure (budget share), $\gamma_{-}(i-j)$ is a commodity price parameter, $\beta \_(i-j)$ is a parameter of the expenditure, $\mathrm{i}$ for dependent variable commodities, and $\mathrm{j}$ for independent variable commodities.

\section{Result and Discussion}

\subsection{Profile area}

According to the Central Java Susenas data (National Socioeconomic Survey) of the year 2016, respondents in this analysis as much as 22,838 households in which is 11,810 households are living in rural areas and 12,028 households in urban areas. Although it is located in the country side this area becomes a food production center. However, households in the country side more allocate the expenses for food as much as $53.17 \%$, while in urban areas amounted to only 45.84\% (Badan Pusat Statistik, 2017). This explains the tendency of larger food needs experienced by households in rural than in urban areas.

\subsection{Food Consumption Preference}

The results of the analysis note that rice remains the main food for every household in Central Java. It is based on the proportion of expenditure in the aggregate; commodity rice reached $93.77 \%$ compared to other commodities such as maize $(0.54 \%)$, wheat flour $(3.11 \%)$, sweet potato $(1.13 \%)$, and cassava $(1.42 \%)$ listed in Table 1 . The high proportion of expenditure on rice as a commodity occurred because the amount of consumption of rice is the largest compared with other commodities, reaching $1.42 \mathrm{~kg}$ /capita/week. Plus fees paid reached Rp 9,065/kg. This has to be one of the factors which aspects influenced the Government to seek and to diversify local food (Ariani, 2010; Sibuea, 2015). Beside the rice, the proportion of spending on high wheat flour commodities as much as $3.11 \%$. The proportion of wheat flour consumption spending and greater local food commodities need to be a concern for the Government. The more that Government imported the commodity to fulfill the market demand in meeting the availability of flour (Purwaningsih, et al., 2010).

It is viewed from the demographics, that overall food consumption is higher in rural than urban areas. However, the price paid by households in urban areas is larger than price paid by the people in rural. Thus causing the share of expenditure in urban areas is greater than the rural. This condition is due to the role of households in urban areas only as consumers. In contrast to the rural households, not only as consumers but also as producers of the food itself (Dwiningsih and Pramoni, 2013). This happens also in other developing Countries, such as food consumption in Fillipina (Lantican et al, 2013).

Food diversification efforts have been attempted since the 1980's, such as promoting a variety of refined products from local food in the form of mocaf, analog rice, dried noodles (Agency for food security, 2015). Although the price of every commodity belongs to affordable, but the price of refined local food is still high or almost the same as the price of rice. Therefore, government 
intervention is required to reduce its production costs so that the selling price could become lower (Ismail, 2015).

Table 1: Price, consumption, and Proportion of Food Consumption Expenditure

\begin{tabular}{|c|c|c|c|}
\hline Commodity & $\begin{array}{c}\text { Price } \\
(\mathrm{Rp} / \mathrm{kg})\end{array}$ & $\begin{array}{c}\text { Consumption } \\
\text { (kg/capita/week) }\end{array}$ & Proportion (\%) \\
\hline \multicolumn{4}{|c|}{ Aggregate } \\
\hline Rice & $9.319,68$ & 1,420 & 93,77 \\
\hline Maize & $5.181,81$ & 0,018 & 0,54 \\
\hline Wheat flour & $7.805,06$ & 0,058 & 3,11 \\
\hline Sweet potato & $3.524,99$ & 0,048 & 1,13 \\
\hline Cassava & $2.695,72$ & 0,077 & 1,42 \\
\hline \multicolumn{4}{|c|}{ Rural } \\
\hline Rice & $9.065,04$ & 1,494 & 93,26 \\
\hline Maize & $5.229,77$ & 0,029 & 0,93 \\
\hline Wheat flour & $7.712,35$ & 0,066 & 3,41 \\
\hline Sweet potato & $3.299,73$ & 0,047 & 1,02 \\
\hline Cassava & $2.399,32$ & 0,086 & 1,38 \\
\hline \multicolumn{4}{|c|}{ Urban } \\
\hline Rice & $9.607,73$ & 1,344 & 94,34 \\
\hline Maize & $4.818,58$ & 0,006 & 0,12 \\
\hline Wheat flour & $7.930,10$ & 0,050 & 2,81 \\
\hline Sweet potato & $3.747,56$ & 0,049 & 1,26 \\
\hline Cassava & $3.081,72$ & 0,068 & 1,47 \\
\hline
\end{tabular}

Source: Susenas (2016), Author calculations

\subsection{Testing Restriction of Food Demand Estimation}

Testing restriction aims to let the results of demand analysis with LA/AIDS model in accordance with the theory of demand. Testing restriction of each model system in the form of homogeneity restrction and symmetry through the Wald Test. Restriction received if the probability value is less than zero. The results of the Wald Test on the Table 2 noted that all model systems has a probability value less than zero, so that the model can be used.

Table 2: Wald Test for Homogeneity and Symmetry Restrction of LA/AIDS Model

\begin{tabular}{lcc}
\hline Restriction & Wald test & Prob \\
\hline & Aggregate & $<, 0001$ \\
Homogeneity & 3,31 & $<, 0001$ \\
Symmetry & 817,18 & \\
\hline & Rural area & $<, 0001$ \\
Homogeneity & 1,66 & $<, 0001$ \\
Symmetry & 700,24 & \\
\hline & Urban Area & $<, 0001$ \\
Homogeneity & 1,86 & $<, 0001$ \\
Symmetry & 803,54 & \\
\hline
\end{tabular}

Source: Susenas (2016), Author calculations 


\subsection{Expenditure Elasticity and Marginal Expenditure Share}

Analysis of the expenditure elasticity used to figure out the impact resulted from changes in expenditure against the changes of demand (Hirshleifer, 1985). While the marginal expenditure shares analysis is used to find out the rate of change in the allocation of the expenditure share of a commodity in the future when there are changes in expenditures (Asare and Eghan, 2012).

Table 3: Expenditure Elasticity and Marginal Expenditure share

\begin{tabular}{lccccccc}
\hline \multirow{2}{*}{ Commodities } & \multicolumn{3}{c}{ Expenditure Elasticity } & & \multicolumn{3}{c}{ Marginal Expenditure Share } \\
\cline { 2 - 3 } \cline { 7 - 8 } & Aggregate & Rural & Urban & & Aggregate & Rural & Urban \\
\hline Rice & 1,060 & 1,058 & 1,066 & & 0,550 & 0,532 & 0,624 \\
Maize & 1,009 & 0,999 & 0,995 & & 0,289 & 0,343 & 0,169 \\
Wheat flour & 0,329 & 1,468 & 0,462 & & 0,008 & $-0,005$ & 0,014 \\
Sweet potato & 0,909 & 0,923 & 0,906 & & 0,082 & 0,079 & 0,097 \\
Cassava & 0,882 & 0,919 & 0,888 & & 0,070 & 0,066 & 0,096 \\
\hline
\end{tabular}

Source: Susenas (2016), Author calculations

Table 3 describes the value of the expenditure elasticity of demand analysis was positive, which mean that the increase of income will arises the demand for food (Hirshleifer, 1985). Expenditure elasticity of rice has more than one value, so that the majority of households in Central Java is good in rural as well as urban, rice as a superior commodity. This illustrates the dependency towards rice is still high because households will continue to increase the amount of consumption along with the increase in income to a certain age. The value of the margin expenditure share of rice is also the highest compared with other commodities. The changes of budgeting to the commodities of rice consumption per household in the future can reach more than $50 \%$. This condition is inversely proportional to the efforts of the Government to reduce the consumption of rice and increase local food (Ariani, 2010), the difference between the value of commodity expenditure elasticity of rice and local food commodities which reached 0.178 to 0.731 percent.

In addition, it needs to concern that the attempt to anticipate the turn of consumption commodities of rice to wheat flour, especially for rural households. It is a given that the value of elasticity second-highest expenditures occur in wheat flour and valued negatively which connotes that when there is a decrease in income, households in rural areas prefer to consume wheat (Purwaningsih et al, 2010) the more if the availability of flour supported by importing form other countries.

\subsection{Price Elasticity}

The results of the analysis in Table 4 are known the values of the price elasticity of every commodity are inelastic and negative. Price elasticity is negative in accordance with the curve of the function is called with the request or downward slopping (Variant, 2010). So if the price changes on any commodity, the value of commodity demand change not greater than price changes. This is the case also with the demand elasticity of food in Sudan in which the value of the price elasticity of the commodity is negative (Hasab and Abdelrahman, 1990). 
Among other commodities, rice is the highest inelastic rate. The value of the inelastic commodity rice greater than other commodities, in the rural (0.912) on Marshallian approach, as well as in all the Hicksian approach analysis on -0.404 (aggregate), -0.417 (rural), and -0.357 (urban). This illustrates a dependency against consumption of rice in Central Java is still high, judging from the demand for rice that its inelasticity almost occurs in all analyses. The results of the analysis of price elasticity explained if the food diversification program to local food for Central Java province can be said to be not optimal to do because it's still high dependence towards the demand of rice. So, the more It is strengthening other research conducted nationally (Airini, 2010), Eastern Indonesia Area (Salliem, 2002), and in West Java (Miranti, 2017).

Beside the rice, wheat flour has a commodity level wich is inelastic. Seen from the Marshallian approach analysis results in the aggregate (-0.763) or urban (0.808) is shown in table 4 . It is again stressed that efforts to diversify food diversity in the form of diversifying food consumption in Central Java more leads against the consumption of wheat flour because aside from commodity rice only food demand of wheat flour that potentially become inelastic. Plus also the growth rate of consumption of wheat flour is also positive i.e. it reaches $10 \%$.

The rice and wheat flour as food diversification efforts target thus have an inelastic price elasticity values. This indicates that the presence of an indication of the failure of efforts to diversify the food on a national scale also occurred in the province of Central Java. Local food commodities that became the goal of food diversification efforts despite having a value that is inelastic, but tends to lead to a degree of elasticity that elastic because its value almost approaching one, which occurred in commodities cassava in urban analysis approach either Marshallian (-0937) and Hicksian approach (-0828) or Hicksian approach in the aggregate (0840).

\subsection{Cross Price Elasticity}

The result of the cross price elasticity analysis on Table 4 explains that most of the commodities have a relationship between positive or substitutional, while most other commodities provide a negative response or as a complementary commodity (Hirshleifer, 1985). Several commodities have the same relationships, Marshallian and Hicksian approach. However, some commodities have a relationship different from both approaches. It is clear that there is a role of income securities against the total effect of the Marshallian approach. When the income effect is greater than the substitution effect, so that the total effect is positive, then the commodities have a positive relationship. Whereas if smaller income effect of the substitution effect, resulting in a total negative effects, then the commodity has a negative relationship. Different case with the Hicksian approach that has only a substitution effects (Anindita, 2008; Nicholson, 1995).

The cross price elasticity of demand for food in Central Java through the Marshallian and Hicksian approach in the aggregate, explaining all commodities have positive relationship or substituted between commodities (Table 4). While in rural, the relationship with other commodities wheat flour is complementary with rice (-1.141), maize (1.301), sweet potatoes (1.558), and casscava (-1.572) on the Hicksian approach. But judging from the Marshallian approach, only cassava which has a complementary relationship with other commodities in rural and urban areas. If the Hicksian approach, all of the commodities substituted except wheat flour 
in the rural. Rising prices of other commodities influence the increase of the demand for rice and occurs in all approaches as well as the area analysed.

But the thing to note is the commodities that are experiencing the highest increase in demand when rice price increased were occurred in wheat flour. These conditions naturally become the things to note. Considering the Government sought to diversify local food, but that happened in Central Java is precisely that the increase in rice prices are likely to have an impact against the rising of wheat flour demand become higher than the local commodities. Advance on wheat flour commodities in rural, where the increase of flour consumption in line with the increase in the consumption of rice. So an idea that until now the consumption patterns are formed in Central Java tends to be on one pattern, rice and flour both in rural and urban. Therefore, in addition in continuing to seek diversified food, the Government should still maintain the affordability commodities/rice, given that the dependence of the rice is still high.

Table 4: Price and Cross Price Elasticity for Marshallian and Hicksian Approach

\begin{tabular}{|c|c|c|c|c|c|c|c|c|c|c|}
\hline \multirow[t]{2}{*}{ Commodities } & \multicolumn{5}{|c|}{ Marshallian } & \multicolumn{5}{|c|}{ Hicksian } \\
\hline & Rice & Maize & $\begin{array}{l}\text { Wheat } \\
\text { flour }\end{array}$ & $\begin{array}{l}\text { Sweet } \\
\text { potato }\end{array}$ & Cassava & Rice & Maize & $\begin{array}{l}\text { Wheat } \\
\text { flour }\end{array}$ & $\begin{array}{l}\text { Sweet } \\
\text { potato }\end{array}$ & Cassava \\
\hline & \multicolumn{10}{|c|}{ Agregat } \\
\hline Rice & $-0,915$ & 0,081 & 0,077 & 0,078 & 0,078 & $\mid-0,404$ & 0,363 & 0,101 & 0,168 & 0,157 \\
\hline Maize & 0,071 & $-0,929$ & 0,069 & 0,070 & 0,070 & 0,588 & $-0,644$ & 0,093 & 0,160 & 0,149 \\
\hline Wheat flour & 0,123 & 0,176 & $-0,763$ & 0,221 & 0,224 & 0,761 & 0,529 & $-0,733$ & 0,334 & 0,323 \\
\hline Sweet potato & 0,071 & 0,077 & 0,082 & $-0,919$ & 0,081 & 0,602 & 0,369 & 0,107 & $-0,826$ & 0,163 \\
\hline \multirow[t]{2}{*}{ Cassava } & 0,068 & 0,073 & 0,079 & 0,077 & -0.922 & 0,598 & 0,365 & 0,103 & 0,170 & $-0,840$ \\
\hline & \multicolumn{10}{|c|}{ Rural } \\
\hline Rice & $-0,912$ & 0,085 & 0,080 & 0,082 & 0,081 & $\mid-0,417$ & 0,423 & 0,077 & 0,166 & 0,152 \\
\hline Maize & 0,068 & $-0,933$ & 0,063 & 0,064 & 0,064 & 0,566 & $-0,593$ & 0,060 & 0,149 & 0,135 \\
\hline Wheat flour & $-0,544$ & $-0,893$ & $-2,651$ & $-1,456$ & $-1,486$ & $-1,141$ & $-1,301$ & $-2,647$ & $-1,558$ & $-1,572$ \\
\hline Sweet potato & 0,074 & 0,077 & 0,083 & $-0,918$ & 0,083 & $\underline{0,586}$ & 0,426 & 0,080 & $-\mathbf{0 , 8 3 0}$ & 0,155 \\
\hline \multirow[t]{2}{*}{ Cassava } & $-0,012$ & $-0,008$ & $-0,001$ & $-0,003$ & $-0,921$ & 0,583 & 0,423 & 0,077 & 0,166 & $-0,847$ \\
\hline & \multicolumn{10}{|c|}{ Urban } \\
\hline Rice & $-0,935$ & 0,060 & 0,058 & 0,059 & 0,059 & $\mid-0,357$ & 0,227 & 0,087 & 0,165 & 0,166 \\
\hline Maize & 0,072 & $-0,927$ & 0,073 & 0,073 & 0,073 & 0,658 & $-0,757$ & 0,102 & 0,180 & 0,181 \\
\hline Wheat flour & 0,094 & 0,167 & $-0,808$ & 0,178 & 0,178 & 0,782 & 0,366 & $-0,774$ & 0,304 & 0,305 \\
\hline Sweet potato & 0,068 & 0,072 & 0,074 & $-0,926$ & 0,073 & 0,660 & 0,244 & 0,104 & $-0,818$ & 0,182 \\
\hline Cassava & $-0,002$ & $-0,001$ & $-0,001$ & $-0,001$ & $-0,937$ & 0,649 & 0,233 & 0,093 & 0,171 & $-0,828$ \\
\hline
\end{tabular}

Source: Susenas (2016), Author calculations

\section{Conclusion and Suggestion}

The results of the research can be concluded that the diversification efforts of primary food in Central Java is still not optimal in its achievement, seen from dependence towards rice still high for households in rural and urban areas. In addition, households in Central Java will also continue to increase the demand for rice along with the increase of revenue, as well as the budget 
for consuming commodities would still continue to increase up to a certain limit. So the Government still needs to maintain the affordability of the availability and the price of rice by the community given that the dependence of the rice consumption is still high. Nevertheless, the Government still has to realize food diversification efforts through providing full support efforts of local food processing industry, as well as introducing a variety of traditional snacks made from local food in formal events.

\section{References}

[1] Anindita, ratya. 2008. Pendekatan Ekonomi untuk Analisis Harga. Edisi Pertama Cetakan ke-1. Jakarta: Kencana Prenada Media Group.

[2] Ariani, Mewa. 2010. Analisis Konsumsi Pangan Tingkat Masyarakat Mendukung Pencapaian Diversifikasi Pangan. Gizi Indonesia. Volume 33(1). Hal 20-28.

[3] Asare dan Eghan. 2012. Food Price Inflation And Consumer Welfare in Ghana. International Journal of Food and Agricultural Economic. Volume 1. Nomor 1 pp 27-39. ISSN 2147-8988

[4] Badan Ketahanan Pangan. 2014. Rencana Strategi Badan Ketahanan Pangan Tahun 2015-2019. Jakarta. Kementerian Pertanian

[5] Badan Pusat Statistik, 2017a. Rata-Rata Pengeluaran Per Kapita Sebulan Menurut Kelompok Barang (rupiah), 2013-2015. Data Online. [https://www.bps.go.id/ linkTabelStatis/view/id/966]. Acces at March, 10th 2017.

[6] Badan Pusat Statistik, 2017b. Provinsi Jawa Tengah Dalam Angka 2017. Semarang. Badan Pusat Statistik Jawa Tengah. ISSN: 0215-2177.

[7] Badan Pusat Statistik, 2017c. Pengeluaran untuk Konsumsi Penduduk Provinsi Jawa Tengah 2016. Semarang. Badan Pusat Statistik Jawa Tengah. ISSN: 978-602-0916-95-8.

[8] Crosetto, Paolo. 2010. Problem Set IV: UMP, EMP, Indirect utility, Expenditure. Handout. Economics form the Departement of Economic (IDEAS) of the University of Milano.

[9] Deaton, A dan Muellbauer. 1980. An Almost Ideal Demand System. The American Economic Review. Published by American Economic Association. Volume 70, Nomor 3 (Jun. 1980), pp 312-326.

[10] Hasab dan Abdelrahman. 1990. Analysis of The Consumer Demand for Cereals Using AIDS model: An Application to Sudan. Amerika Serikat. Lowa State University

[11] Hirshleifer, Jack. 1985. Teori Harga dan Penerapannya Edisi Ketiga. Jakarta: Erlangga

[12] Ismail, Muhammad. 2015. Diversifikasi Pangan. Online. [http://www.solopos.com/ 2015/05/29/diversifikasi-pangan-biaya-produksi-mahal-produk-olahan-singkong-wonogiri-sulitberkembang-609081]. Access at November. 5 th 2017

[13] Kementerian Pertanian. 2015. Statistik Konsumsi Pangan Tahun 2015. Pusat Data dan Sistem Informasi Pertanian. Jakarta: Pusat Data dan Sistem Informasi Pertanian Sekretariat Jendral Kementerian Pertanian.

[14] Koutsoyiannis. 1982. Modern Microeconomic. Second Edition. Southeast Asian Reprint. Hongkong: The Macmillan Press Ltd.

[15] Liao dan Chern. 2007. A Dynamic Analysis of Food Demand Patterns in Urban China. Selected Paper prepared for presentation at the American Agricultural Economics Association Annual Meeting. Portlan

[16] Lantican, Sombilla, dan Quilloy. 2013. Estimating the Demand Elasticities of Rice in the Philippines. Phillipine. SEARCA. ISBN 978-971-560-159-7.

[17] Miranti, astari. 2017. Tesis. Pengaruh Pendapatan dan Harga Pangan Terhadap Tingkat Diversifikasi Pangan Rumah Tangga di Provinsi Jawa Barat. Bogor. Institut Pertanian Bogor

[18] Nicholson, Walter. 1995. Mikroekonomi Intermediate dan Aplikasinya Edisi Kelima Jilid Satu. Jakarta: Binarupa Aksara. 
[19] Purwaningsih, Hartono, Masyhuri, dan Handoyo. 2010. Pola Pengeluaran Pangan Rumah Tangga Menurut Tingkat Ketahanan Pangan di Provinsi Jawa Tengah. Jurnal Ekonomi Pembangunan. Volume 11 Nomor 2, hal 236-253.

[20] Saliem, Handawi. 2002. Analisis Permintaan Pangan di Kawasan Timur Indonesia. Jurnal Agro Ekonomi. Litbang Kementerian Pertanian. Volume 20 Nomor 2. Oktober 2002: hal 64-91.

[21] Sibuea, posman 2015. Upaya Mengurangi Konsumsi Beras. Online. [http://news. metrotvnews.com/read/2015/05/08/394940/upaya-mengurangi-konsumsi-beras]. Access at November, 15th 2017.

[22] United States Departement of Agriculutre. 2017. Wheat: World Markets and Trade. Online. [https://www.fas.usda.gov/data/grain-world-markets-and-trade]. Access at November, 5th 2017.

[23] Varian, Hal. R. 2010. Intermediate Microeconomics A Modern Approach. 8th Edition. London. W.W. Norton \& Company. ISBN: 978-0-393-93424-3.

[24] Zellner, Arnold. 1962. An Efficient Method of Estimating Seemingly Unrelated Regressions and Test for Aggregation Bias. Source: Journal of the American tatistical Association. Volume 57 Nomor 298 (Jun. 1962), pp. 248-368

*Corresponding author.

E-mail address: laurensius1@ yahoo.co.id 